\title{
Online Discussion in a Hybrid Information Literacy Credit Course
}

\author{
Warren N. Jacobs, California State University, Stanislaus
}

\begin{abstract}
This article discusses how an instruction librarian created an online learning community of adult learners in a hybrid, credit-bearing information literacy course. The Blackboard course management system was utilized for weekly course discussion on ethical issues involving the use of information to promote student engagement in the critical evaluation of information, collaboration with members of the online learning community, and construction of new learning through the synthesis of course curriculum with prior learning.
\end{abstract}

Since the opening of California State University, Stanislaus in 1960 (California State University [CSU], Stanislaus, 2006a), instruction librarians have taught adult learners to recognize their need for information, retrieve information efficiently and effectively from a wide array of resources, critically evaluate information, and use information ethically and legally for course assignments or lifelong learning (Association of College and Research Libraries [ACRL], 2000). Due to the rapid advances in the technology used to deliver information, the library's instructional program has evolved over the past decade to keep pace (Dupuis, 1999).

\section{SSCI 3005}

In 1995, the CSU inaugurated the system-wide Information Competence Initiative to encourage the collaboration of teaching faculty and instruction librarians in the integration of information literacy skills into the learning outcomes of all academic courses (Curzon, 2000; Rockman, 2003; Roth, 1999). An annual competitive grant process results in an average grant of $\$ 5,000$ to be used for faculty training, librarian release time, curriculum development, and the creation of credit courses, tutorials, and assessments (Curzon, 2000; Rockman, 2003; Roth, 1999).

A partnership between the University Library and the Social Science department resulted in a successful collaboration in which instruction librarians teach SSCI 3005, a semester-long information literacy credit course open to any adult learner and required for all Social Science majors at CSU Stanislaus. Within SSCl 3005, students survey a wide range of research resources including article databases, print and online reference sources, statistical information, government documents, Internet search engines, and Web sites. Students learn to structure searches to enhance the relevance and precision of results, critically evaluate information, and utilize correct citation format to document sources.

\section{Stockton}

A section of SSCI 3005 meets at the university's branch campus in Stockton, located over fifty miles from the main campus in Turlock. Stockton is a diverse city in California's Central Valley, a rich agricultural region (City of Stockton, 2006). 68\% of Stockton's 280,000 residents are recognized as minorities, with Hispanics identified as the largest demographic group with over 79,000 residents, one third of the city's population (City of Stockton, 2007).

Adult learners commute to a campus that is located downtown in a previously rundown, crime-ridden area of the city that is now being redeveloped. Many students are the first generation of their family to strive for a college education. Students face a multitude of challenges that may include family and work 
responsibilities, low income, lack of access to computer technology and other needed support services, and a sense of isolation from the majority of students who take classes at the main campus in Turlock. Of the 8137 students enrolled at CSU Stanislaus in fall 2005, 973 were identified as Stockton students. More than two thirds of the Stockton students were women, and over twenty percent were Hispanic (CSU Stanislaus, 2006b).

Stockton students receive library services through a library access center [LAC]. The LAC contains a reference collection, reserve materials for the courses taught in Stockton, popular reading materials, computers with Internet access, and a librarian to assist with course-related research. Materials from the main library may be ordered online and delivered to the LAC via a courier service. When SSCI 3005 is taught in Stockton, emphasis is placed on the use of electronic resources since students do not have the opportunity to utilize an extensive print collection in the LAC.

\section{Blackboard}

After teaching SSCI 3005 for one semester, I decided to revise the course to empower Stockton students to construct their own learning through the use of critical thinking skills, engagement with the curriculum between the weekly class meetings, and development of an online learning community.

Utilizing the university's course management system, Blackboard version 6.3, SSCI 3005 was converted from a traditional face-to-face format into a hybrid format in which a significant portion of the course was presented online. After the revisions, students were required to enter Blackboard to access course curriculum, readings, and links to relevant Web resources; read announcements, communicate via course e-mail, view their grades, and participate in weekly discussions.

As with other course management systems, Blackboard offers an accessible platform to facilitate the delivery of online information literacy instruction and assessment of learning by simplifying the process of uploading assignments and curriculum, posting announcements, and generating class discussion (Cox, 2002; Curl, Reynolds, Mai, \& Macklin, 2000; Getty, Burd, Burns, \& Piele, 2000; Shneiderman, 2007).

Cheating and plagiarism have been increasing, so authentication of a student's identity in an online environment remains an important issue of academic integrity (Olt, 2002). Blackboard requires a login and password tied to a student's university ID to prevent unauthorized access to assessments and grading modules (Olt, 2002; Rowe, 2004). Since the instructor chooses the permission settings in Blackboard, vandalism of discussion postings is less likely than the use of a wiki where students may have permission to edit anyone else's posts.

Due to students' familiarity with Blackboard from other courses, there was less of a learning curve than other technology alternatives, including blogs and wikis freely available via the Internet. Centralizing the course in one platform allowed adult learners more time to fully engage with the course curriculum and exercise their critical thinking skills to consider the issues associated with the use of information (Ellis, 2004; Viggiano \& Ault, 2001).

\section{Teaching in a Hybrid Format}

Instruction librarians face many challenges when teaching in a hybrid format, including the challenge of fostering student learning while teaching online (Buchanan, 2001). Teaching in a Web-based environment calls for the instruction librarian to facilitate the adult learner's active participation in the construction of his/her learning (Buchanan, 2001; Buchanan, Xie, Brown, \& Wolfram, 2001; Edwards, 2000; Hootstein, 2002; Small, 1999).

Student-librarian interaction is vital and requires more time in hybrid classes (Graham, Cagiltay, Lim, Craner, \& Duffy, 2001; Viggiano \& Ault, 2001). Instruction librarians must communicate their expectations for student participation, assignment deadlines, timely feedback on completed assignments, and provide 
assistance with technical issues (E.Buchanan, et al., 2001; Graham, et al., 2001; Hoffman, 2002; Wilner \& Lee, 2002).

Instruction librarians require far more time for course preparation and curriculum design while teaching online versus teaching in a traditional classroom (Buchanan, 1999; E. Buchanan, et al., 2001; Pachnowski \& Jurczyk, 2003; Small, 1999). During the development phase, instruction librarians should factor in additional time to deal with a host of technical and design problems that may arise (Hoffman, 2002; Jacobs, 2001; Kraemer, 2003).

The delivery of instruction in a hybrid format requires students and instruction librarians to take a nontraditional look at education. A willingness to meet challenges and take risks is inherent for success (Buchanan, 1999). Online learning may not serve the instructional needs of all adult learners based on the rate of attrition (Buchanan, 2001). Some students are not prepared to learn online (Manual, 2001). Adult learners should carefully consider whether to undertake learning in a hybrid format predicated on their independence, assertiveness, time management, study skills, writing proficiency, and computer literacy (Buchanan, 1999). Students who visit the Blackboard course site several times per week, keep up with readings, participate in group projects, and complete assignments in a timely fashion are most likely to be successful (Curl, et al., 2000).

Design principles account for the pedagogical differences in the way that instruction is delivered in Blackboard versus classroom instruction (Stevens-Long \& Crowell, 2002). Students should know what is expected of them (Vignettes for Training, 2000). Good instruction begins by clarifying objectives (Dewald, 1999a). Superior objectives tell students what they are expected to learn under specific conditions, how the objective will be measured, and the time period in which the learning is expected to take place (Vignettes for Training 2000). While these principles operate in face-to-face instruction, their specificity and clarity are vital in online settings.

Traditional classroom information literacy instruction reaches those students who come to the library, while a hybrid course meets the need for instruction in the critical evaluation of information when adult learners cannot come to campus regularly (ACRL, 2000; ACRL, 2004; Edwards, 2000; Gutierrez \& Wang, 2001). Students receiving instruction in a hybrid format achieve higher learning outcomes than students receiving instruction solely in a Web-based format through the use of learning communities to foster collaboration (Buchanan, 1999; Churkovich \& Oughtred, 2002; Curl, et al., 2000).

\section{Discussion Forums}

Learning takes place through the dynamic construction, rather than the passive accumulation of knowledge, and instruction corroborates the knowledge built by learners rather than merely communicating facts (Nanjappa \& Grant, 2003). Adult learners are actively engaged in synthesizing new learning with prior knowledge through respectful debate with classmates in the discussion forum (Clawson, Deen, \& Oxley, 2002; Dewald, Scholz-Crane, Booth, \& Levine, 2000). Instruction librarians foster the application of learning through discussion assignments requiring analysis and problem-solving (Clawson et al., 2002; "Constructivism," 2001; Dewald et al., 2000).

Within the realm of analysis, It is important for adult learners to construct an understanding of the process of critical evaluation of information ("Constructivism," 2001). Instruction librarians should design curriculum to teach concepts, rather than technique. To understand concepts, students construct knowledge that promotes higher order thinking, collaboration among learners, reduced feelings of isolation, and respect for diverse viewpoints and individual learning styles (Alexander \& Smith, 2001; Carnevale, 2001; "Constructivism," 2001; Fleming, 2001; Graham, et al., 2001; Hootstein, 2002; Kassop, 2003; Nanjappa \& Grant, 2003; Saunders, 2002; Small, 1999; Tobin \& Kesselman, 1999; Yi, 2005).

Class discussion allows for a collaborative, interactive, and supportive learning environment (Barr \& Tagg, 1995; Buchanan, 1999; E. Buchanan, et al., 2001; Dewald, 1999b; Graham, et al., 2001). Through interactivity, including hands-on practice and discovery learning, students construct and apply new 
knowledge based on previous learning, multiple intelligences, and varied learning styles (Brown, 1997; ChanLin \& Chang, 2003; "Constructivism," 2001; Dewald, 1999b; Ellis, 2004; Fleming, 2001; "Multiple intelligences," 2001; Saunders, 2002; Yi, 2005).

Asynchronous discussion postings allow time for contemplation and research, providing richer communication than either synchronous chat, e-mail, or face-to-face discussion (E. Buchanan, et al., 2001). With adequate time to review previous postings and incorporate new research, students feel less self-conscious about sharing their opinions than students in a traditional face-to-face classroom. Due to the nature of computer-mediated communication, status differences are minimized in the discussion forum (Emberger, 2001).

\section{Developing an Online Learning Community}

Within an online learning community, adult learners discuss ethical issues related to the critical evaluation of information; collaborate on assignments, share resources, and express support and encouragement while interacting on a personal level (Emberger, 2001). Hybrid information literacy instruction is effective at enhancing the sense of online community among course participants. The use of active learning and varied methods of communication aid in the retention of concepts, and foster an environment that encourages participation and equality integral to the success of the online learning community (Dewald et al., 2000; Haythornthwaite, Kazmer, Robins, \& Shoemaker, 2000; Rovai, 2002).

To build a thriving, diverse, and inclusive online learning community, instruction librarians must define the community's purpose, promote student contributions to the discussion, define the guidelines for appropriate postings, model best practices of online communication using netiquette, and allow community members to resolve their own disputes before becoming involved (E. Buchanan, et al., 2001). To facilitate the development of an online learning community, instruction librarians establish goals and define learning outcomes, design assignments to encourage collaboration, use icebreaking and team building activities to create a sense of community in the course, monitor student learning and adjust course requirements as necessary, and furnish timely feedback on discussions and assignments ( $E$. Buchanan, et al., 2001).

Trust and social capital are essential ingredients of an online learning community. Trust enables members of an online learning community to work together to realize shared goals. Each time a member of the learning community demonstrates that he/she can be counted upon to meet commitments, social capital is multiplied and trust is extended (Fu, 2004). Shared expectations and goals, supported by commitment and honesty, help members of the learning community discuss issues related to course content, collaborate on assignments, share resources, critically evaluate their classmate's work, and express support and encouragement (Fu, 2004; Manuel, 2001). Rules for behavior exist, roles are defined, and relationships have structure (Fu, 2004; Haythornthwaite, et al., 2000). An online learning community also requires the flow of information to ensure social capital (Haythornthwaite, et al., 2000; Putnam, n.d.; Rovai, 2002).

Community building is important to aid in the retention of students while raising their sense of well-being (Rovai, 2002). The best practices of online learning communities keep adult learners connected even at a distance (Kassop, 2003). Interactive discussions provide a supportive, collaborative, and cooperative environment to enhance student learning ("Building learning communities," 2000; Donaldson, 2000; Rovai, 2002).

\section{SSCI 3005 Course Discussion}

The SSCI 3005 course discussions focused on issues involving the ethical, legal, and economic use of information including Internet filtering, online plagiarism, inadvertent plagiarism by historians and authors, data mining, copyright, and identity theft. Through the synthesis of assigned course readings, additional research to support a student's individual position on these issues, and respectful debate with 
classmates, adult learners constructed their own learning through the process of critically evaluating each of the major issues associated with the ethical use of information.

Discussion assignments built upon one another, creating a foundation for library research in support of course assignments and lifelong learning. Adult learners developed critical thinking and problem solving abilities through the synthesis of new instruction with prior learning (Clark, 2003; ChanLin \& Chang, 2003; Buchanan, Luck, \& Jones, 2002b).

An optional lounge forum was created as a location where students could communicate off topic. The lounge forum contributed to the effectiveness of the online learning community by providing adult learners with a safe place to discuss personal matters (Emberger, 2001). SSCl 3005 students communicated about the high cost of textbooks, and shared job announcements with their classmates.

To ensure that all students received the assistance they needed to be successful in SSCI 3005, a help forum was created for questions regarding the course curriculum or assignments. Students were advised to post their questions relevant to the entire class in this forum so that all members of the class would benefit from my response. Students were directed to send personal questions to me via e-mail. During the semester, optional help forums were created for questions regarding the comprehensive annotated bibliography assignment and the final examination.

The first week's discussion assignment required adult learners to read netiquette guidelines and a sample posting. In an effort to build community, students introduced themselves to their classmates. Each posting was to include a student's academic standing, goals for the course, research interests, hobbies, and any other information that they wanted to share with the class. Students were required to respond to at least two classmates during the week utilizing the best practices of online discussion to ensure respectful communication with their colleagues.

The following week, students were asked to post their research topic, and state why they selected that topic for the semester-long annotated bibliography assignment. Students were asked to address the strategies they utilized to ensure a comprehensive search for the best resources on their research topic. After their initial posting, students were required to respond to at least two classmates with comments, suggestions, and encouragement to help them find the best resources on their research topics.

Throughout the course, other discussion topics related to the curriculum included the best resource found on an adult learner's specific research topic, a student's individual progress in acquiring research skills, and the best resources found in support of the annotated bibliography assignment.

At the end of the semester, members of the online learning community were asked to post on their individual accomplishments during the semester, as well as anything they still wanted to learn about research that may not have been covered in SSCI 3005. Students were to include a short message of gratitude to friends, family, or colleagues who helped along the way.

To promote greater engagement with the critical evaluation of information, students were required to read specific articles linked through Blackboard or available via the library's databases on controversial issues involving the ethical use of information. The first discussion asked for students' opinions with regard to whether libraries should be required to place filters on public Internet computers, and whether the blocking of Web sites is a form of censorship or simply a means to prevent harm to children. Students were asked to consider whether filtering should be limited to children's computers or should also include computers used by adults, who decides whether information is considered to be objectionable, and what standards should be applied to this process.

Respectful debate was encouraged with an emphasis on the use of scholarly research to support one's opinion. Before posting, students were advised to view the sample posting for an example of how to prepare a discussion posting on a controversial issue by citing scholarly research in support of their individual viewpoint. After their initial posting, students were required to respond to one classmate who agreed with their position on this issue and to one classmate who disagreed with their opinion. 
Adult learners were required to treat everyone in the class with respect in the discussion forum, demonstrating sensitivity for language, social, and cultural differences that may impact the efficacy and timeliness of the course discussion (Clarke, 2000). Consideration for the privacy of others was also encouraged. Student postings were expected to be succinct. Forums were typically kept open until the following week's class meeting to encourage students to stay on track with the weekly reading and discussion assignments. Students could still read postings from previous weeks.

Other controversial topics that were discussed in Blackboard after students completed assigned readings include the ethical implications of a California community college instructor completing an online course utilizing a false identity, the discovery of plagiarism by prominent historians and authors, the growing problem of identity theft and misuse of personal information, and the ethical and legal implications of data mining.

There were several disappointing aspects to the use of discussion forums in SSCI 3005. Some adult learners waited until the last second to post their response to questions or interact with their classmates. Many of the adult learners simply agreed with their classmates in order to receive credit for participation. A symposium format is often unfamiliar to undergraduates and may account for the difficulty in debating and discussing ethical issues regarding the use of information (Manual, 2001).

In order for students to receive full credit for participation in the discussion in future semesters, in the future I will require students to post on different days with a minimum of three postings per week. Students will be expected to provide reasons for their agreement or disagreement with other members of the online learning community. To avoid burnout, each week there will be regularly scheduled days on which there will be no posting.

Despite Blackboard's spell-check feature, many students' postings were barely legible with spelling and grammatical errors. In an effort to encourage future students to put more time and thought into completing the discussion assignment, spelling and grammatical errors will result in point deductions.

I expected adult learners to utilize research to support their opinions, but few of them did. Students often failed to provide the citation to the literature they were paraphrasing, or failed to provide a complete reference. In the future, to encourage adult learners to make better use of research to support their position on an issue, and to ensure that students properly cite their sources, I will provide more examples of discussion postings supported by research, and repeated instruction in formatting references throughout the semester.

As an instructor of the course, the experience of facilitating an online community of adult learners fully engaged with the ethical issues regarding the use of information proved to be a rewarding experience. When adult learners felt passionately about an issue while debating a classmate who took the opposite view, the quality of postings improved markedly. An example was the issue of Internet filtering. Parents of young children were almost strident in their defense of filtering in public libraries. Other members of the online learning community were just as outspoken in defense of freedom of information, making for a lively debate. A few students utilized other research, Web sites, and personal narrative to support their particular viewpoint, even if the citations weren't formatted perfectly.

\section{Suggestions for future research}

Future research opportunities on the use of discussion forums in hybrid information literacy credit courses such as SSCl 3005 will require pre- and post-testing of adult learners to determine if their level of engagement in the weekly discussion assignment has a direct correlation in the adult learner's level of information competence.

\section{Conclusion}


With so much information available in an online format, students require information literacy and research skills (Buchanan, Jones, \& Luck, 2002a). Hybrid information literacy instruction utilizing online discussion forums helps students become better consumers of information while using the Web-based format in which they actively search for information. Information literate students actively think about information and critically evaluate information rather than passively receiving facts (Dewald et al., 2000). Information literacy instruction encourages lifelong learning by helping students develop the skills they need to use information more effectively and efficiently (ACRL, 2000; Kassop, 2003; Orr, Appleton, \& Wallin, 2001).

\section{References}

Alexander, L. B., \& Smith, R. C. (2001). Research findings of a library skills instruction course. Portal: Libraries and the Academy, 1(3), 309-328.

Association of College and Research Libraries. (2000). Information literacy competency standards for higher education. Retrieved May 20, 2007, from http://www.ala.org/ala/acrl/acrlstandards/ standards.pdf

Association of College and Research Libraries. (2004). Guidelines for distance learning library services. Retrieved May 20, 2007, from http://www.ala.org/ala/acrl/acrlstandards/ guidelinesdistancelearning.htm

Barr, R. B., \& Tagg, J. (1995). From teaching to learning: A new paradigm for undergraduate education. Change, 27(6), 12-25.

Brown, A. (1997). Designing for learning: What are the essential features of an effective online course. Australian Journal of Educational Technology, 13(2), 115-126.

Buchanan, E. A. (1999). Assessment measures: Pre-tests for successful distance teaching and learning. Online Journal of Distance Learning Administration, 2(3). Retrieved May 20, 2007, from http:// www.westga.edu/ -distance/buchanan24.html

Buchanan, E. A. (2001). The scholarship of teaching and learning in undergraduate distance education. Academic Exchange Quarterly, 5(2), 138-143.

Buchanan, E., Xie, H., Brown, M., \& Wolfram, D. (2001). A systematic study of Web-based and traditional instruction in an MLIS program: Success factors and implications for curriculum design. Journal of Education for Library and Information Science, 42(4), 274-288.

Buchanan, L.E., Jones, T.C., \& Luck, D.L. (2002a). Collaborating online to teach information and multimedia literacy. Paper presented at the meeting of the Mid-South Instructional Technology Conference, Murfreesboro, TN. Retrieved May 20, 2007, from http://www.mtsu.edu/ itconf/ proceed02/50.html

Buchanan, L. E., Luck, D. L., \& Jones, T. C. (2002b). Integrating information literacy into the virtual university: A course model. Library Trends, 51(2), 144-166.

Building learning communities in the online classroom: Tips for success. (2000). Charlottesville, VA: Piedmont Virginia Community College. Retrieved May 20, 2007, from http://sapphire.pvcc.cc.va. us/teachingcenter/tutorials/tips\%20for\%20building\%20learning\%20 communities.htm

California State University, Stanislaus 2006-2007 undergraduate catalog. (2006a). Turlock, CA: California State University, Stanislaus.

California State University, Stanislaus fall 2005 campus data portfolio. (2006b). Turlock, CA: California State University, Stanislaus. Retrieved May 16, 2007, from http://130.17.202.107/ html/pub/cdp/ index.html

Carnevale, D. (2001, April 13). Assessment takes center stage in online learning. The Chronicle of Higher Education, 47(31), 43-45.

ChanLin, L.-J., \& Chang, C.-C. (2003). Web-based library instruction for promoting information skills. Journal of Instructional Psychology, 30(4), 265-275.

Churkovich, M., \& Oughtred, C. (2002). Can an online tutorial pass the test for library instruction? An evaluation and comparison of library skills instruction methods for first year students at Deakin University. Australian Academic and Research Libraries, 33(1), 25-38.

City of Stockton. (2006). 2006 Stockton community profile [Data file]. Retrieved May 17, 2007, from http:// www.stocktongov.com/EconDev/documents/CommunityProfile.pdf 
City of Stockton. (2007). Population, housing, and income data for the city of Stockton [Data file]. Retrieved May 16, 2007, from http://www.stocktongov.com/CD/pages/documents/PopHousinghandout_000.pdf

Clark, R. C. (2003). Building expertise: Cognitive methods for training and performance improvement. Silver Spring, MD: International Society for Performance Improvement.

Clawson, R. A., Deen, R. E., \& Oxley, Z. M. (2002). Online discussions across three universities: Student participation and pedagogy. PS: Political Science and Politics, 35(4), 713-717.

Constructivism. (2001). Livingston, NJ: Funderstanding. Retrieved May 20, 2007, from http://www. funderstanding.com/constructivism.cfm

Cox, C. N. (2002). Becoming part of the course: Using Blackboard to extend one-shot library instruction. College \& Research Libraries News, 63(1), 11-13, 39.

Curl, S. R., Reynolds, L. J., Mai, B. A., \& Macklin, A. E. S. (2000). Reality check: Asynchronous instruction works! College \& Research Libraries News, 61(7), 586-588.

Curzon, S. C. (2000). Developing a program of information literacy: How California State University did it. College \& Research Libraries News, 61(6), 483-486, 491.

Dewald, N. H. (1999a). Transporting good library instruction practices into the Web environment: An analysis of online tutorials. The Journal of Academic Librarianship, 25(1), 26-32.

Dewald, N. H. (1999b). Web-based library instruction: What is good pedagogy? Information Technology and Libraries, 18(1), 26-31.

Dewald, N. H., Scholz-Crane, A., Booth, A., \& Levine, C. (2000). Information literacy at a distance: Instructional design issues. The Journal of Academic Librarianship, 26(1), 33-44.

Donaldson, K. A. (2000). Library research success: Designing an online tutorial to teach information literacy skills to first-year students. The Internet and Higher Education, 2(4), 237-251.

Dupuis, E. A. (1999). The creative evolution of library instruction. Reference Services Review, 27(3), 287291.

Edwards, R. (2000). Web tutorials for education students: A practical alternative to traditional library instruction-basic issues and concerns. Behavioral and Social Sciences Librarian, 18(2), 17-25.

Ellis, L. A. (2004). Approaches to teaching through digital reference. Reference Services Review, 32(2), 103-119.

Emberger, M. (2001, Spring). Cooperative learning: The missing ingredient for school improvement. International Association for the Study of Cooperation in Education Newsletter: $20(1), \quad 2$. Retrieved May 20, 2007, from http://www.iasce.net/Newsletters/2001 Spring/20 1 page 2. shtml

Fleming, N. (2001). VARK: A guide to learning styles. Retrieved May 20, 2007, from http://www.varklearn.com/english/index.asp

Fu, Q. (2004). Trust, social capital, and organizational effectiveness. Blacksburg, VA: Virginia Polytechnic Institute and State University Retrieved May 20, 2007, from http://scholar.lib.vt.edu/theses/ available/etd-05122004-155926/unrestricted/qhfumajorpaper.pdf

Getty, N. K., Burd, B., Burns, S. K., \& Piele, L. (2000). Using courseware to deliver library instruction via the Web: Four examples. Reference Services Review, 28(4), 349-359.

Graham, C., Cagiltay, K., Lim, B., Craner, J., \& Duffy, T.M. (2001). Seven principles of effective teaching: A practical lens for evaluating online courses. The Technology Source. Retrieved May 20, 2007, from http://technologysource.org/article/seven_principles_of_effective_teaching/

Gutierrez, C., \& Wang, J. (2001). A comparison of an electronic vs. print workbook for information literacy instruction. The Journal of Academic Librarianship, 27(3), 208-212.

Haythornthwaite, C., Kazmer, M. M., Robins, J., \& Shoemaker, S. (2000). Community development among distance learners: Temporal and technological dimensions. Journal of Computer Mediated Communication, 6(1). Retrieved May 20, 2007, from hptp://jcmc.indiana.edu/vol6/issue1/ haythornthwaite.html

Hoffman, P. S. (2002). The development and evolution of a university-based online library instruction course. Reference Services Review, 30(3), 198-211.

Hootstein, E. (2002). Wearing four pairs of shoes: The roles of e-learning facilitators. Learning Circuits. Retrieved May 29, 2007, from http://www.learningcircuits.org/2002/oct2002/elearn.html

Jacobs, M. (2001). Speakeasy studio and café: Information literacy, Web-based library instruction, and technology. Information Technology and Libraries, 20(2), 66-71. 
Kassop, M. (2003). Ten ways online education matches, or surpasses, face-to-face learning. The Technology Source. Retrieved May 29, 2007, from http://technologysource.org/article/ ten_ways_ online_education_matches_or_surpasses_facetoface_learning/

Kraemer, E.W. (2003). Developing the online learning environment: The pros and cons of using WebCT for library instruction. Information Technology and Libraries, 22(2), 87-92.

Manuel, K. (2001). Teaching an online information literacy course. Reference Services Review, 29(3), 219-229.

Multiple intelligences. (2001). Livingston, NJ: Funderstanding. Retrieved May 29, 2007, from http://www.funderstanding.com/multiple_intelligence.cfm

Nanjappa, A., \& Grant, M. M. (2003). Constructing on constructivism: The role of technology. Electronic Journal for the Integration of Technology in Education, 2(1). Retrieved May 29, 2007, from http://ejite.isu.edu/Volume2No1/Nanjappa.htm

Olt, M. R. (2002). Ethics and distance education: Strategies for minimizing academic dishonesty in online assessment. Online Journal of Distance Learning Administration, 5(3). Retrieved May 28, 2007, from http://www.westga.edu/ distance/ojdla/fall53/olt53.html

Orr, D., Appleton, M., \& Wallin, M. (2001). Information literacy and flexible delivery: Creating a conceptual framework and model. The Journal of Academic Librarianship, 27(6), 457-463.

Pachnowski, L. M., \& Jurczyk, J. P. (2003). Perceptions of faculty on the effect of distance learning technology on faculty preparation time. Online Journal of Distance Learning Administration, 6(3). Retrieved May 29, 2007, from http://www.westga.edu/ distance/ojdla/fall63/pachnowski64.html

Putnam, R. D. (n.d.). Social capital: What is it? Retrieved May 5, 2007, from http://www.bowlingalone. com/socialcapital.php3

Rockman, I. F. (2003). Integrating information literacy into the learning outcomes of academic disciplines: A critical $21^{\text {st }}$ century issue. College \& Research Libraries News, 64(9), 612-615.

Roth, L. (1999). Educating the cut-and-paste generation. Library Journal, 124(18), 42-44.

Rovai, A.P. (2002). Building sense of community at a distance. International Review of Research in Open and Distance Learning, 3(1). Retrieved May 29, 2007, from http://www.irrodl.org/index.php/ irrodl/article/view/79/153

Rowe, N. C. (2004). Cheating in online student assessment: Beyond plagiarism. Online Journal of Distance Learning Administration, 7(2). Retrieved May 29, 2007, from http://www.westga.edu/ $\sim$ distance/ojdla/summer72/rowe72.html

Saunders, L. (2002). Teaching the library: Best practices. Library Philosophy and Practice, 4(2). Retrieved May 29, 2007, from http://www.webpages.uidaho.edu/ mbolin/saunders.pdf

Setting training objectives and task analysis. (2000). Duarte, CA: Vignettes for Training. Retrieved February 21, 2007, from http://vignettestraining.com/pdfstt_1s.pdf

Shneiderman, B. (2007). Human needs and the new computing technologies: Interview with the author. Retrieved May 29, 2007, from http://mitpress. mit.edu/catalog/item/default.asp?ttype=2\&tid=9091\& xid $=13 \&$ xcid $=2189$

Small, R. (1999). A comparison of resident and distance learning experience in library and information science graduate education. JELIS, 40(1), 27-40.

Stevens-Long, J., \& Crowell, C. (2002). The design and delivery of interactive online graduate education. In K. E. Rudestam \& J. Schoenholtz-Read (Eds.), Handbook of Online Learning: Innovations in Higher Education and Corporate Training (pp. 151-169). Thousand Oaks, CA: Sage.

Tobin, T., \& Kesselman, M. (1999). Evaluation of Web-based library instruction programs. Paper presented at the International Federation of Library Associations and Institutions, Bangkok, Thailand. Retrieved May 29, 2007, from http://www.ifla.org/IV/ifla65/papers/102-163e.htm

Viggiano, R., \& Ault, M. (2001). Online library instruction for online students. Information Technology and Libraries, 20(3), 135-138.

Wilner, A., \& Lee, J. (2002). The promise and the reality of distance education. NEAUpdate, 8(3). Retrieved May 29, 2007, from http://www2.nea.org/he/heupdate/images/vol8no3.pdf

Yi, H. (2005). Library instruction goes online. Library Review, 54(1), 47-58.

Warren Jacobs is a Reference/Instruction Librarian at California State University, Stanislaus. E-mail: wjacobs@csustan.edu 